This is an Accepted Manuscript of an article published by Taylor \& Francis Group in Conflict, Security and Development on 11 Jun 2019, available online:

http://www.tandfonline.com/10.1080/14678802.2019.1608016.

Neo-Ottomanism, Eurasianism or securing the region? A longer view on

Turkey's interventionism

\title{
Clemens Hoffmann
}

[2,650 words]

Bio: Clemens Hoffmann is a lecturer in International Politics at the University of Stirling,

UK. He has previously held positions at Bilkent University, Ankara, and the University of Sussex from where he received his $\mathrm{PhD}$ in 2010. He works on Turkish foreign policy and the geo-political ecology of the Middle East using approaches from historical sociology and Marxist International Relations theory.

\section{Abstract:}

Few observers will have noticed that Turkey is second only to the US in having large parts of its army stationed abroad. This contribution will focus on these interventions - which are diverse in nature and political origin. Featuring the second largest territorial army within NATO and only recently exploring its regional and, to some extent, global geopolitical ambitions, Turkey's interventionism is ambiguous and remains difficult to make sense of. While Turkey's interventions may not confront Western interests to the same extent Russia's do, operations like in Cyprus, nevertheless cause a general sense of unease about this middleranking regional power conducting large scale military interventions. While many are not directly sanctioned, others are outright opposed by 
the West. Starting from Turkey's participation in the Korean War, there is, conversely, a longer history of Turkey playing an integral role in Western interventionism. More recently, Turkey's involvement in the Middle East, and particularly in Syria, has given rise to claims that it continues to pursue a 'neo-Ottoman' foreign policy. The short history presented here reflects on the politically awkward position Turkey's interventionism takes up in between ambitions for regional hegemony, a rising global power and an integral part of the liberal Western order.

Conventional approaches to intervention and liberal state building assume Western agency albeit more often than not implemented through international organisations such as the UN. While there are exceptions, regional powers tend to conduct operations in line with Western objectives where their interests intersect with 'universal' liberal interventionist goals, frequently under the umbrella of regional organisations.

Turkey's regional military actions do not fit these conventional patterns. Neither directly supporting nor outright opposing the West as a whole, the second largest territorial army within NATO pursues regional and increasingly global geopolitical ambitions of which it is difficult to make sense. While Turkey's interventions may not confront Western interests in the same way Russia's do, some certainly clash with those of individual Western powers, notably of the United States. ${ }^{1}$ Ever since its first minor incursions in Cyprus in 1964 to its contemporary large-scale interventions in Syria and Iraq, there is a general sense of unease about this middle-ranking regional power conducting large scale military interventions, most of which are not directly sanctioned by any international institution.

Far from these making Turkey a renegade member of the Western alliance, these regional operations in fact obscure Turkey's long-standing integral role in Western 
interventionism. Most notable are Turkish involvement in the Korean War, in NATO missions in Afghanistan, as well as other NATO operations, such as those in the former Yugoslavia. These are frequently forgotten as attention focuses on Turkey's independent interventions in its immediate geopolitical environment. Debates on recent regional interventions are more developed, partly because they constitute a significant departure from Turkey's traditional policy based on territorial saturation and, precisely, non-intervention.

Most accounts associate this alleged departure from established principles with Turkey's potential or actual 'neo-Ottoman', 'pan-Islamist'” or 'Eurasianist' ${ }^{\text {'4 }}$ foreign policy 'turn'. This contrast between Turkey's 'old' Westernism and 'new' independence naturalises its NATO membership which emerged out of a particular historical conjuncture, motivated by specific geopolitical conditions. Having established a strong sense of isolationism after its War of Independence in 1923, Turkey developed from an anti-colonial into a pro-Western power in 1952 as a result of Stalin's designs on Turkish territory. ${ }^{5}$ The commitment to territorial saturation encapsulated in Ataturk's famous "Peace at Home, Peace Abroad" formula remained. Having committed to the anti-communist camp with its contribution to the Korean War and the Baghdad Pact, Turkey became a pillar in the American-led order in the Middle East, especially after the 'loss' of Iran in 1979. So, while Turkey’s foreign policy orientation was defensive, its departure from the non-aligned into the Western camp, made explicit during the Bandung conference, was only gradual and never without contradictions.

Turkey's career as an independent interventionist power started during the first signs of conflict in Cyprus during the 1960s, when plans for an intervention on behalf of the Turkish Cypriot minority were drawn up. The 1974 Cyprus intervention was initially legitimized by Turkey's right to protect the Turkish Cypriot community under the Treaty of Guarantee after a coup d'état backed by the Greek military junta aimed for a unification with Greece. Over the years, the intervention turned into a full-scale military occupation of the island's north, 
which was not backed by international law and opposed by Turkey's NATO allies. Despite Turkey's importance in a Middle East framed by Cold War geopolitics, the US administration reacted with an arms embargo against its ally. Criticisms of what many, including many Turkish Cypriots, now label a form of colonialism, ${ }^{6}$ is easily obscured by what is effectively a purely Greek Cypriot administration's efforts to isolate and penalise the Turkish part of its citizenry. Despite this structural discrimination, the magnitude of Turkey's military presence (including control over the Turkish Cypriot civil police force), socio-economic penetration, and increasing levels of political influence, leave no doubt about its de-facto client status with little to no independence from mainland Turkey. Turkish Cyprus, despite having developed independently from Turkey under British colonial rule, is referred to as 'Yavru Vatan', or 'Baby Fatherland' by many Turks.

This longer view on Turkey's interventionism demonstrates that despite the recent alleged 'failure' of the 'Turkish Model' for the 'New Middle East' ${ }^{7}$ its regional activism is not a new development. It is embedded within a much larger expansion of Turkey not only as a regional, but also a global 'Emerging Power' ${ }^{8}$ with high levels of foreign investment, frequently in the construction sector, all across Africa, ${ }^{9}$ up to the Western Balkans ${ }^{10}$ and all the way to Latin America. ${ }^{11}$ While only partially related to this expansion of Turkish capital, Turkey's interventionism not only follows 'security concerns' and 'national interest' in a narrow sense. It has always had strong ethno-political dimensions, as Turkey declared itself the protector of all Turkic peoples. This pronounced ethnic dimension was reflected in Turkey's 'Pan-Turanist' foreign policy initiative, and the first wave of trade expansion towards the East after its liberal opening following the 1980 coup d'état. This element is not only strong rhetorically, but also militarily, as Turkmen militia frequently serve as proxies for Turkish interests in Iraq and Syria. This has now been complemented by a new rhetoric of protecting all Sunni populations against potential or actual aggression. Interventions are 
selectively justified in ethno-nationalist or sectarian terms, identifying potential or actual ethnic adversaries to be replaced by 'rightful owners', usually of ethno-religious background considered to be loyal to Turkey. ${ }^{12}$

This underpins most notably Turkey’s 2016 'Euphrates Shield’ and 2018 'Olive Branch' operations in northern Syria. As a result of these interventions by an alliance of the Turkish Armed forces and loyal Syrian militia operating under the 'Free Syrian Army' (FSA) label, Turkey now controls the entire stretch of its southern border with Syria from Afrin to the Western bank of the Euphrates river. This is accompanied by what appears to have become a continued effort of sui generis Turkish 'state building'. ${ }^{13}$ Ostensibly these operations were directed against Daesh and the Kurdistan Worker's Party (PKK) affiliated YPG/YPJ Syrian Kurdish forces, which were in the process of unifying a statelet along Turkey's southern border. Backed by US military support for their anti-IS struggle, the YPG controlled 'cantons' declared autonomy and established a northern Syrian federation, scheduled elections and built state structures. Ankara considers these an existential threat due to their ideological affiliation with the PKK, which Turkey has committed to 'neutralise' since the 1990s.

While operations in northern Syria aim at (at least temporary) direct control, there is a more complex Turkish involvement in other parts of Syria. Turkey established itself as a major power broker in the Astana peace process, in fact entering an alliance with Russia and Iran, despite being on opposite sides in the Syrian civil war, thus inspiring allegations of a 'Eurasian’ foreign policy shift. Areas in Idlib province, for instance, have Turkish military forces but are not under full and formal Turkish control. Initially this intervention, mainly directed by the Turkish intelligence agency MIT, was intended to provide a safe haven for anti-regime forces. This would realise the regional vision of creating an AKP-friendly environment through an association with the Muslim Brotherhood in one part of Syria. 
Having failed both regionally and in Syria, this vision has now turned into a liability, whereby Turkey's radicalised former clients could cause potential harm to the areas under Turkish occupation and also within Turkey. Continued Russian-supported advances by the regime beg questions about the terms and stability of the Russo-Turkish rapprochement, thus increasing the value of territories that Turkey directly and fully controls as safe havens for its client rebels.

Turkey's interventions are, in all their diversity, thus characterized by three continuities. First, they emanate from what Ankara identifies as geopolitical or security necessities. Just like the emergence of a Syrian Kurdish state along its southern borders and the PKK's activities in northern Iraq are portrayed as existential threats, so was the 1974 coup d'état in Cyprus an inevitable casus belli. Despite political polarisation, there is strong cross-party support for the current interventions in Syria and Iraq. Second, despite recent talk of a more ambitious and potentially even global role, most Turkish interventions remain regional for now. Related, third, is that even if a more realist Turkish security interest is claimed to be at stake, most interventions are partly justified by a pan-Turanic 'duty of care' for what are regarded as ethnic clients under pressure.

There are three recent developments that may change this picture. The first concerns the establishment of new bases further afield, notably. in Qatar, Somalia and, most recently, Sudan. These indicate an ambition to project maritime power in the region. The deployments in Qatar and Sudan in particular have caused former allies Saudi Arabia and the United Arab Emirates to view Turkey increasingly as more of a threat than an ally. ${ }^{14}$ This comes after a fall out with Egypt over President Mohamad Morsi's deposition, leaving Qatar as the only meaningful Arab ally. Establishing a presence at geopolitically-sensitive locations in the Persian Gulf and the Horn of Africa, far from Turkey's immediate environment and, therefore, without a direct security implication for its territorial integrity, signifies active 
regional geopolitical competition. Beyond the Middle East, Turkey has also started being more present and vocal in southeast Asia. Both regions are identified as having majority Muslim populations receptive for Turkish interests, economic or otherwise. Hence, the hard, regional security and ethnic Turkic dimension to Turkey's interventionism is now complemented by a naval element around the Red Sea as well as a 'soft' pan-Islamist expansion with potentially global reach.

Yet more significant are changes in Turkey's state building ambitions in the areas it controls. Though it gained some experience providing aid to Northern Cyprus, these circumstances were highly specific, not least because of ethno-linguistic commonality. While operations in Iraq remain entirely military and security oriented, Somalia and northern Syria have now become fields for experimenting with post-conflict development and state building entirely led by Turkish institutions and know-how. Both are loosely associated with the UN's state building principles and borrow plenty of practices and policies from Western humanitarianism. Turkish state building efforts are nevertheless for the most part run independently from the West. In northern Syria, Turkey is trying to build a civil administration with elements of the Free Syrian Army (FSA), and a host of Turkish public and government-loyal NGOs providing essential public services including security. ${ }^{15}$ Central to these efforts is the Turkish disaster relief agency AFAD, which also manages Syrian refugee camps in Turkey. Apart from infrastructure reconstruction, these efforts include health and education as well as the security sector. Reconstruction follows the imperative of the Turkish state being in firm control of all processes, including allocation of contracts to Turkish firms. Despite commitment to FSA control, the Turkish Armed Forces (TSK) retain a full occupying force. This also means, however, that Western institutions, including UN agencies, while applauding Turkey's refugee efforts at home, express concerns over the lack of access or insight into the operation. The areas remain de-facto under full Turkish control 
and are mainly there to contain Kurdish state building efforts. The Turkish activities borrow much from Western liberal practice; however, they are also intended as a showcase for an independent Turkish development approach and the capabilities of the Turkish state in general. Not least, the areas mitigate any new refugee pressures, provide safe havens for client fighters displaced from other areas of Syria, but also constitute Turkish bargaining chips in any future peace negotiations for Syria.

Beyond the public commitment to deal with this 'existential' or other threats to Turkey’s security, the long-term intentions for Syria after any potential settlement remain obscure. They reach from a passive-defensive damage limitation to claims about an outright 'neo-Ottoman' expansionism and territorial revisionism of the 1923 Lausanne borders, sometimes labelled the 'Golden Apple' vision for Turkey. Though not formally occupied like the area between Afrin and Jarablus in northern Syria, similar observations can be made about northern Iraq, where Turkey maintains a military presence and has recently upscaled ground operations against areas under PKK control. Even prior to military operations, the region ruled by the Kurdish Regional Government (KRG) is heavily influenced by Turkey, including commercially. Oil exports are controlled by Turkey via its Ceyhan port, ${ }^{16}$ while large scale infrastructure and property investments are dominated by Turkish construction conglomerates. Interestingly, reconstruction efforts in Iraq and elsewhere come at a time when the US administration has repeatedly verbalised its withdrawal from such activities in the region.

Much of the role of Turkey as a semi-independent intervening power reflects the politically awkward position its interventionism takes between ambitions for regional hegemony, rising global power, and integral part of the old Western order. While full of contradictions, this is not a new position for Turkey. Turkey's interventionism follows a longer tradition, transcending the perceived divide between the 'old' and 'new' or 'West' and 
'East'. The semi-colonial nature of the contemporary occupations of northern Syria and Cyprus suggests that Turkey's interventionist agenda is neither outright neo-Ottoman, nor entirely anti-colonial, but is dynamic and constantly evolving under rapidly shifting geopolitical circumstances.

In sum, Turkey's interventions, both prior and during the AKP era, are motivated by four key pillars. First, the Western style securitization of its geopolitical environment, mostly motivated by the fight against the PKK, but also including the protection of minorities considered to be ethnically Turkic. Second, it is impossible to fully understand Turkey's Eurasianist repositioning without its energy-hungry growth ambitions. Lacking sizeable resources of its own, both Russia and Iran are indispensable partners, forcing some difficult 'Eurasian' compromises on Turkey, especially in Idlib. This is embedded, third, within an agenda of competitive regional power projection. This, indeed, follows historic Ottoman, but also pan-Turanic lines, reaching all the way from Sarajevo deep into the Red Sea. Attempting to gain strategic salience through partnerships with the Muslim Brotherhood or Qatar is viewed as without alternative by Ankara, but this has generated additional problems with most Arab states, notably Egypt and Saudi Arabia, all of which are now firmly opposed to Turkey’s regional ambitions. Finally, from Bülent Ecevit giving in to popular demands for intervention in Cyprus to the contemporary widespread elite and popular support of military intervention in Syria and Iraq, military action abroad nurtures a populist militarist nationalism at home. Domestic considerations, such as the 2018 parliamentary and presidential elections, therefore, constitute a determinant of Turkish interventionism. It is this element and the resonance of anti-Western rhetoric that makes a clash of geopolitical interests between Washington and Ankara appear less of a threat and more of an opportunity to the current Turkish leadership. 


\section{Bibliography}

Akçali, E. and M. Perinçek. 2009. Kemalist Eurasianism: An Emerging Geopolitical Discourse in Turkey, Geopolitics 14. 550-569

al-Khateb, K. 2018.Turkey props up industrial zone in Syria's al-Bab. Available at http://www.al-monitor.com/pulse/originals/2018/02/syria-al-bab-euphrates-shieldindustrial-area-turkey.html [accessed 20/05/2018]

Candar, C. 2018. Deadly Ankara-West fault line cracks open at Syria's Manbij. Available at http://www.al-monitor.com/pulse/originals/2018/04/turkey-united-states-syria-manbijbecomes-fault-line.html [accessed 23/05/2018]

Cardoso, A. and E. Turhan. 2018. Examining new geographies of coal: Dissenting energyscapes in Colombia and Turkey, Applied Energy 224. 398-408.

Coş, K. and P. Bilgin. 2010. Stalin's Demands: Constructions of the "Soviet Other" in Turkey’s Foreign Policy, 1919-1945, Foreign Policy Analysis 6. 43-60.

Economist. 2018. After taking Afrin, Turkey looks for new targets in Syria. https://www.economist.com/middle-east-and-africa/2018/03/22/after-taking-afrinturkey-looks-for-new-targets-in-syria. [accessed 14/05/2018]

Ekinci, M. U. 2014. A golden age of relations: Turkey and the Western Balkans during the AK party period. Insight Turkey 16.1. 103-125.

Kubicek, P., E. P. Dal, and H. T. Oğuzlu, eds. 2016. Turkey's Rise as an Emerging Power. Routledge, London.

Moudouros, N. 2017. The 'New Homeland' and Turkish Cypriot Opposition in the 1974-1981 Period, The Cyprus Review 29. 135-158.

Ozkan, M. 2013. Does "rising power" mean "rising donor”? Turkey's development aid in Africa. Africa Review 5.2.139-147

Tuğal, C. 2007. Nato’s Islamists, New Left Review. 5-34. 
Tuğal, C. 2016. The Fall of the Turkish Model: How the Arab Uprisings Brought Down Islamic Liberalism, Verso, London.

Yavuz, H. 1998 Turkish identity and foreign policy in flux: The rise of Neo-Ottomanism, Middle East Critique 7. 19-41.

\section{Endnotes}

\footnotetext{
${ }^{1}$ Candar, Deadly Ankara-West fault line cracks open at Syria's Manbij

2 Yavuz, Turkish identity and foreign policy in flux: The rise of Neo-Ottomanism

${ }^{3}$ Tuğal, Nato's Islamists

${ }^{4}$ Akçali and Perinçek, Kemalist Eurasianism: An Emerging Geopolitical Discourse in Turkey

${ }^{5}$ Coş and Bilgin, Stalin's Demands: Constructions of the "Soviet Other" in Turkey's Foreign Policy, 1919-1945

${ }^{6}$ Moudouros, The 'New Homeland' and Turkish Cypriot Opposition in the 1974-1981 Period

7 Tuğal, The Fall of the Turkish Model: How the Arab Uprisings Brought Down Islamic Liberalism

${ }^{8}$ Kubicek, Dal, and Oğuzlu, Turkey's Rise as an Emerging Power

${ }^{9}$ Ozkan. Does "rising power" mean "rising donor"? Turkey's development aid in Africa

${ }^{10}$ Ekinci, $A$ golden age of relations: Turkey and the Western Balkans during the AK party period

${ }^{11}$ Cardoso and Turhan. Examining new geographies of coal: Dissenting energyscapes in Colombia and Turkey

${ }^{12}$ Economist, After taking Afrin, Turkey looks for new targets in Syria

${ }^{13}$ al-Khateb, Turkey props up Industrial Zone in Syria's al-Bab

${ }^{14}$ Moubayed, Turkish base in Sudan a problem for Arab powers

${ }^{15}$ Haid, Post-ISIS Governance in Jarablus: A Turkish-led Strategy

${ }^{16}$ Ant and Khalid, Turkey Warns Iraq Kurds It Can 'Close the Valves' on Oil Exports
} 